\title{
Radio analytical technique in characterization of nuclear grade ion exchangers Duolite ARA-9366B and Purolite NRW-5010
}

Pravin U Singare

\begin{abstract}
Background: lon exchange is one of the widely used techniques in nuclear industries for treatment of liquid radioactive waste. Regular efforts are being made in order to develop new ion exchange resins and their subsequent characterization so as to bring about efficient industrial performance. Among the different characterization techniques, radioactive tracer technique is one of the sensitive analytical techniques, mainly because of its non-destructive nature, high detection sensitivity, capability of in-situ detection, and physico-chemical compatibility with the material under study. The present work was therefore performed to demonstrate the application of the radioactive tracer technique in performance evaluation of two closely related nuclear grade anion exchange resins Duolite ARA-9366B and Purolite NRW-5010.

Methods: The short-lived radioisotope ${ }^{131} \mathrm{I}$ and ${ }^{82} \mathrm{Br}$ were used in the present experimental work to trace the kinetics of iodide and bromide ion-isotopic exchange reactions. The radioactivity was measured at various time intervals using $\gamma$-ray spectrometer having well type $\mathrm{Nal}(\mathrm{TI})$ scintillation detector of Nucleonix make. From the radioactivity measured at various time intervals, the values of specific reaction rate $\left(\mathrm{min}^{-1}\right)$, amount of ion exchanged (mmol), and initial rate of ion exchange $(\mathrm{mmol} / \mathrm{min})$ were calculated.

Results: It was observed that for iodide ion-isotopic exchange reaction under identical experimental conditions of $30.0^{\circ} \mathrm{C}, 1.000 \mathrm{~g}$ of ion exchange resins and $0.001 \mathrm{~mol} / \mathrm{L}$ labeled iodide ion solution, the above values were calculated as $0.246,0.155$, and 0.038 , respectively for Purolite NRW-5010 resin, which was higher than the respective values of 0.201, 0.139 , and 0.028 obtained for Duolite ARA-9366B resins. The identical trend was observed for the two resins during bromide ion-isotopic exchange reaction.

Conclusions: The overall results indicate that under identical experimental conditions, Purolite NRW-5010 resins exhibit superior performance over Duolite ARA-9366B resins. The same technique can be extended further for performance evaluation of different nuclear as well as non-nuclear grade ion exchange resins.
\end{abstract}

Keywords: Nuclear grade resins; Duolite ARA-9366B; Purolite NRW-5010; Characterization; Reaction kinetics; Ion-isotopic exchange reactions

\section{Background}

There are a number of liquid processes and waste streams at nuclear facilities (i.e., nuclear power plants, fuel reprocessing plants, nuclear research centers, etc.) that require treatment for process chemistry control reasons and/or the removal of radioactive contaminants (IAEA 2002). The treatment processes may be required for reactor primary coolants, the cleanup of spent fuel pools,

Correspondence: pravinsingare@gmail.com

Department of Chemistry, Bhavan's College, Munshi Nagar, Andheri (West), Mumbai 400 058, India liquid radioactive waste management systems, etc. One of the most common treatment methods for such aqueous streams is the ion exchange, which is a well-developed technique that has been employed for many years in both the nuclear industry and in other industries. In spite of its advanced stage of development, various aspects of ion exchange technology are being studied in many countries to improve its efficiency and economy in its application to radioactive waste management. Organic ion exchange resins have been developed over a much longer period of time than the selective inorganic ion exchangers that 
have recently become available in commercial quantities and can now meet the demands of the nuclear industry. The organic ion exchange resins are very effective at transferring the radioactive content of a large volume of liquid into a small volume of solid and have proved to be reliable and effective for the control of both the chemistry and radiochemistry of water coolant systems at nuclear power plants and also for processing some liquid radioactive waste (Samanta et al. 1992; Samanta et al. 1993; Samanta et al. 1995; Kulkarni et al. 1996; Bray et al. 1990). In a number of cases, for specific physical and chemical reasons, organic resins cannot be replaced by commercially available inorganic ion exchangers. Also, organic ion exchange resins are used globally (Tomoi et al. 1997; Zhu et al. 2009; Kumaresan et al. 2006). The selection of an appropriate ion exchange material for treatment of liquid waste is possible on the basis of information provided by the manufacturer. However, since the selection of the appropriate ion-exchange material depends on the needs of the system, it is expected that the data obtained from the actual experimental trials will prove to be more helpful in the characterization and subsequent selection of the resins.

Although there are many alternative methods available for characterization of ion exchange resins (de Villiers et al. 1964; Harland 1994; Zeng et al. 1996; Patel et al. 2004; Liu et al. 2005; Masram et al. 2010), radioactive tracer isotopic technique is one of the sensitive analytical techniques (Sood et al. 2004; IAEA 2004). By monitoring the radioactivity continuously, the migration of the tracer and in turn, of the bulk matter under investigation, can be followed. As a result, radioisotopes have become a useful tool and almost every branch of industry, which uses them (Sood et al. 2004; IAEA 2004), and every radiotracer methodology, is described extensively in the literature (Clark et al. 2011; Dagadu et al. 2012; Koron et al. 2012). Considering the extensive technological application of radioactive tracers, in the present investigation, attempts are made to apply the same technique to study the kinetics of ion-isotopic exchange reactions in nuclear grade anion exchange resins Duolite ARA-9366B and Purolite NRW5010. It is expected that the kinetics data obtained here will not only be used in characterization of these resins but also in standardization of the process parameters for their efficient application.

\section{Methods}

\section{Conditioning of ion exchange resins}

Duolite ARA-9366B (by Auchtel Products Ltd., Mumbai, India) and Purolite NRW-5010 (by Purolite International India Private Limited, Pune, India) are type I strong base, quaternary ammonium, nuclear grade anion exchange resins in hydroxide form. Details regarding the properties of the resins used are given in Table 1. These resins were converted separately in to iodide/bromide form by treatment with $10 \%(w / v) \mathrm{KI} / \mathrm{KBr}$ solution in a conditioning column which is adjusted at the flow rate as $1 \mathrm{~mL} / \mathrm{min}$. The resins were then washed with double distilled water, until the washings were free from iodide/bromide ions as tested by $\mathrm{AgNO}_{3}$ solution. These resins in bromide and iodide form were then dried separately over $\mathrm{P}_{2} \mathrm{O}_{5}$ in desiccators at room temperature.

\section{Radioactive tracer isotopes}

The radioisotope ${ }^{131} \mathrm{I}$ and ${ }^{82} \mathrm{Br}$ used in the present experimental work was obtained from Board of Radiation and Isotope Technology (BRIT), Mumbai, India. Details regarding the isotopes used in the present experimental work are given in Table 2.

Study on kinetics of iodide ion-isotopic exchange reaction In a stoppered bottle $250 \mathrm{~mL}(\mathrm{~V})$ of $0.001 \mathrm{~mol} / \mathrm{L}$ iodide ion solution was labeled with diluted ${ }^{131} \mathrm{I}$ radioactive solution using a micro syringe, such that $1.0 \mathrm{~mL}$ of labeled solution has a radioactivity of around 15,000 counts per minute $(\mathrm{cpm})$ when measured with $\gamma$-ray spectrometer having $\mathrm{NaI}(\mathrm{Tl})$ scintillation detector. The $\gamma$-ray spectrometer used was Type GR 612 supplied by Nucleonix Systems Pvt. Ltd., India, having a well-type scintillation detector of Nucleonix make. Since only about 50 to $100 \mu \mathrm{L}$ of the radioactive iodide ion solution was required for labeling the solution, its concentration will remain unchanged, which was further confirmed by potentiometer titration against $\mathrm{AgNO}_{3}$ solution. The above-labeled solution of known initial activity $\left(A_{i}\right)$ was kept in a thermostat adjusted to $30.0^{\circ} \mathrm{C}$. The swelled and conditioned dry ion exchange resins in iodide form weighing exactly $1.000 \mathrm{~g}$ (m) were transferred quickly into this labeled solution which was vigorously stirred by using a mechanical stirrer and the activity in counts per minute of $1.0 \mathrm{~mL}$ of solution was measured. The solution was transferred back to the same bottle containing labeled solution after measuring activity. The iodide ion-isotopic exchange reaction can be represented as:

$$
\mathrm{R}-\mathrm{I}+\mathrm{I}^{*}{ }_{(\text {aq. })} \rightleftharpoons \mathrm{R}-\mathrm{I}^{*}+\mathrm{I}^{-}{ }_{\text {(aq. })}
$$

Here, R-I represents ion exchange resin in iodide form; $I^{*-}$ (aq.) represents aqueous iodide ion solution labeled with ${ }^{131}$ I radiotracer isotope.

The activity of solution was measured at a fixed interval of every $2.0 \mathrm{~min}$. The final activity $\left(A_{f}\right)$ of the solution was also measured after $3 \mathrm{~h}$ which was sufficient time to attain the equilibrium (Singare et al. 2012; Lokhande et al. 2007; Lokhande et al. 2008a; Lokhande and Singare 2008; Lokhande et al. 2006). The activity measured at various time intervals was corrected for background counts. 
Table 1 Properties of ion exchange resins

\begin{tabular}{|c|c|c|c|c|c|c|c|}
\hline lon exchange resin & Matrix & $\begin{array}{l}\text { Functional } \\
\text { group }\end{array}$ & $\begin{array}{l}\text { Particle } \\
\text { size }(\mathrm{mm})\end{array}$ & $\begin{array}{l}\text { Moisture } \\
\text { content (\%) }\end{array}$ & Operating $\mathrm{pH}$ & $\begin{array}{l}\text { Maximum operating } \\
\text { temperature }\left({ }^{\circ} \mathrm{C}\right)\end{array}$ & $\begin{array}{l}\text { Total exchange } \\
\text { capacity }(\mathrm{mEq} / \mathrm{mL})\end{array}$ \\
\hline Duolite ARA-9366B & $\begin{array}{l}\text { Cross-linked polystyrene } \\
\text { divinylbenzene }\end{array}$ & $-\mathrm{N}^{+} \mathrm{R}_{3}$ & 0.3 to 1.2 & 55 & 0 to 14 & 60 & 1.0 \\
\hline Purolite NRW-5010 & $\begin{array}{l}\text { Cross-linked polystyrene } \\
\text { divinylbenzene }\end{array}$ & $-\mathrm{N}^{+} \mathrm{R}_{3}$ & 0.43 to 1.20 & 60 & 0 to 14 & 60 & 0.8 \\
\hline
\end{tabular}

Similar experiments were carried out by equilibrating separately $1.000 \mathrm{~g}$ of ion exchange resin in iodide form with labeled iodide ion solution of four different concentrations ranging up to $0.004 \mathrm{~mol} / \mathrm{L}$ at a constant temperature of $30.0^{\circ} \mathrm{C}$. The same experimental sets were repeated for higher temperatures up to $45.0^{\circ} \mathrm{C}$.

Study on kinetics of bromide ion-isotopic exchange reaction The experiment was also performed to study the kinetics of bromide ion-isotopic exchange reaction by equilibrating $1.000 \mathrm{~g}$ of ion exchange resin in bromide form with labeled bromide ion solution in the same concentration and temperature range as above. The labeling of bromide ion solution was done by using ${ }^{82} \mathrm{Br}$ as a radioactive tracer isotope for which the same procedure as explained above was followed. The bromide ion-isotopic exchange reaction can be represented as:

$$
\mathrm{R}-\mathrm{Br}+\mathrm{Br}^{*}{ }_{(\text {aq. })} \rightleftharpoons \mathrm{R}-\mathrm{Br}^{*}+\mathrm{Br}^{-}{ }_{\text {(aq. })}
$$

Here, $\mathrm{R}$ - Br represents ion exchange resin in bromide form; $\mathrm{Br}^{*-}$ (aq.) represents aqueous bromide ion solution labeled with ${ }^{82} \mathrm{Br}$ radiotracer isotope.

\section{Results and discussion}

\section{Comparative study of ion-isotopic exchange reactions}

In the present investigation, it was observed that due to the rapid ion-isotopic exchange reaction taking place, the activity of solution decreases rapidly initially, then due to the slow exchange, the activity of the solution decreases slowly and finally remains nearly constant. Preliminary studies show that the above exchange reactions are of first order (Singare and Lokhande 2012; Lokhande and Singare 2007, 2008; Lokhande et al. 2006, 2008a). Therefore, logarithm of activity when plotted against time gives a composite curve in which the activity initially decreases sharply and thereafter very slowly giving nearly straight line (Figure 1). Thus, it is evident that rapid and slow ion- isotopic exchange reactions are occurring simultaneously (Singare and Lokhande 2012; Lokhande and Singare 2007, 2008; Lokhande et al. 2006, 2008a). For both the ionisotopic exchange reactions, using the two resins, the ion exchange process is film diffusion controlled during an initial short period and the tendency toward particle diffusion control increases as exchange continues (Lokhande et al. 2008b). Presumably, the rapid exchange process taking place during the initial short period was film diffusion controlled; while the slow exchange process near the end was particle diffusion controlled. The specific reaction rate for the rapid process was obtained by resolving the composite curve as is done to determine the decay constants of radioactive isotopes in a mixture. The rapid process is completed in a short time, but the slow process continues for a much longer time. At the late stage, the slow exchange is the only reaction that takes place, and the logarithm of activity (cpm) curve against time is a straight line. Now, the straight line was extrapolated back to zero time. The extrapolated portion represents the contribution of slow process to the total activity which now includes rapid process also. The activity, due to slow process, was subtracted from the total activity at various time intervals. The difference gives the activity due to the rapid process only. From the activity exchanged due to rapid process at various time intervals, the specific reaction rates $(k)$ of rapid ion-isotopic exchange reaction were calculated. The amount of iodide/bromide ions exchanged ( $\mathrm{mmol}$ ) on the resin were obtained from the initial and final activities of solution and the amount of exchangeable ions in $250 \mathrm{~mL}$ of solution. From the amount of ions exchanged on the resin $(\mathrm{mmol})$ and the specific reaction rates $\left(\mathrm{min}^{-1}\right)$, the initial rate of ion exchanged $(\mathrm{mmol} / \mathrm{min}$ ) was calculated.

Because of the larger solvated size of bromide ions as compared to that of iodide ions, it was observed that the exchange of bromide ions occurs at the slower rate than that of iodide ions. Hence, under identical experimental conditions, the values of specific reaction rate $\left(\mathrm{min}^{-1}\right)$,

Table 2 Properties of ${ }^{131} \mathrm{I}$ and ${ }^{82} \mathrm{Br}$ tracer isotopes (Sood et al. 2004)

\begin{tabular}{llllll}
\hline Isotopes & Half-life & Radioactivity/MBq & y-energy $(\mathbf{M e V})$ & Chemical form & Physical form \\
\hline${ }^{131} \mathrm{I}$ & 8.04 days & 185 & 0.36 & lodide $^{*}$ & Aqueous \\
${ }^{82} \mathrm{Br}$ & $36 \mathrm{~h}$ & 185 & 0.55 & Bromide** $^{*}$ & Aqueous \\
\hline
\end{tabular}

*Sodium iodide in dilute sodium sulfite. ${ }^{*}$ Ammonium bromide in dilute ammonium hydroxide. 


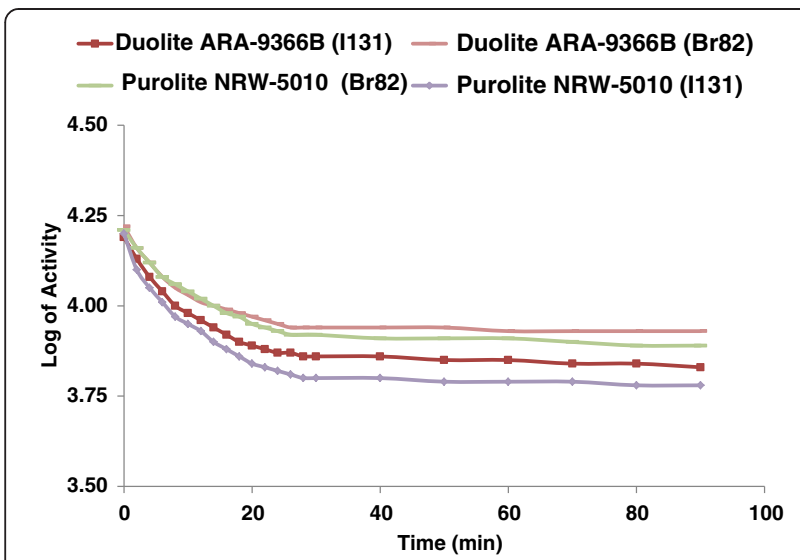

Figure 1 Kinetics of ion-isotopic exchange reactions. Amount of ion exchange resin $=1.000 \mathrm{~g}$. Concentration of labeled exchangeable ionic solution $=0.001 \mathrm{~mol} / \mathrm{L}$. Volume of labeled ionic solution $=250 \mathrm{~mL}$ Temperature $=30.0^{\circ} \mathrm{C}$.

amount of ion exchanged (mmol) and initial rate of ion exchange $(\mathrm{mmol} / \mathrm{min})$ are calculated to be lower for bromide ion-isotopic exchange reaction than that for iodide ion-isotopic exchange reaction as summarized in Tables 3 and 4. For both bromide and iodide ion-isotopic exchange reactions, the value of specific reaction rate increases with increase in the concentration of iodide and bromide ions in solution from $0.001 \mathrm{~mol} / \mathrm{L}$ to $0.004 \mathrm{~mol} / \mathrm{L}$ (Table 3). However, with rise in temperature from $30.0^{\circ} \mathrm{C}$ to $45.0^{\circ} \mathrm{C}$, the specific reaction rate was observed to decrease (Table 4). Thus, in case of Purolite NRW-5010 at $30.0^{\circ} \mathrm{C}$, when the concentration of iodide and bromide ions in solution increases from $0.001 \mathrm{~mol} / \mathrm{L}$ to $0.004 \mathrm{~mol} /$ $\mathrm{L}$, the specific reaction rate value for iodide ion-isotopic exchange increases from 0.246 to $0.290 \mathrm{~min}^{-1}$, while for bromide ion-isotopic exchange, the value increases from 0.203 to $0.245 \mathrm{~min}^{-1}$. Similarly, in the case of Duolite ARA-9366B, the value for iodide ion-isotopic exchange increases from 0.201 to $0.235 \mathrm{~min}^{-1}$, while for bromide ion-isotopic exchange the value increases from 0.165 to $0.186 \mathrm{~min}^{-1}$. However, when the concentration of iodide and bromide ions in solution is kept constant at $0.001 \mathrm{~mol} / \mathrm{L}$ and temperature is raised from $30.0^{\circ} \mathrm{C}$ to $45.0^{\circ} \mathrm{C}$; in the case of Purolite NRW-5010, the specific reaction rate value for iodide ion-isotopic exchange decreases from 0.246 to $0.219 \mathrm{~min}^{-1}$, while for bromide ion-isotopic exchange, the value decreases from 0.203 to $0.178 \mathrm{~min}^{-1}$. Similarly, in case of Duolite ARA-9366B, the specific reaction rate value for iodide ion-isotopic exchange decreases from 0.201 to $0.156 \mathrm{~min}^{-1}$, while for bromide ion-isotopic exchange, the value decreases from 0.165 to $0.125 \mathrm{~min}^{-1}$. From the results, it appears that iodide ion exchange has the faster rate as compared to that of bromide ions which was related to the extent of solvation (Tables 3 and 4).

\section{Comparative study of anion exchange resins}

From the Tables 3 and 4, it is observed that for iodide ion-isotopic exchange reaction using Purolite NRW-5010 resin, the values of specific reaction rate $\left(\mathrm{min}^{-1}\right)$, amount of iodide ion exchanged $(\mathrm{mmol})$, and initial rates of iodide ion exchange $(\mathrm{mmol} / \mathrm{min})$ were $0.246,0.155$, and 0.038 , respectively, which were higher than $0.201,0.139$, and 0.028 , respectively, as that obtained using Duolite ARA9366 B resins under identical experimental conditions of $30.0^{\circ} \mathrm{C}, 1.000 \mathrm{~g}$ of ion exchange resins, and $0.001 \mathrm{~mol} / \mathrm{L}$ labeled iodide ion solution. The identical trend was observed for the two resins during bromide ion-isotopic exchange reaction.

From Table 3, it is observed that using Purolite NRW5010 resins at a constant temperature of $30.0^{\circ} \mathrm{C}$, as the concentration of labeled iodide ion solution, increases from 0.001 to $0.004 \mathrm{~mol} / \mathrm{L}$, the percentage of iodide ions exchanged also increases from $61.80 \%$ to $68.90 \%$ while using Duolite ARA-9366B resins, under identical experimental conditions, the percentage of iodide ions exchanged increases from $55.40 \%$ to $62.90 \%$. Similarly, in the case of bromide ion-isotopic exchange reaction, the percentage of bromide ions exchanged increases from $52.20 \%$ to $55.70 \%$ using Purolite NRW-5010 resin, while for Duolite ARA-9366B resin, it increases from $48.30 \%$ to $52.80 \%$. The effect of ionic concentration on the percentage of ions exchanged is graphically represented in Figure 2.

From Table 4, it is observed that using Purolite NRW5010 resins, for $0.001 \mathrm{~mol} / \mathrm{L}$ labeled iodide ion solution, as the temperature increases from $30.0^{\circ} \mathrm{C}$ to $45.0^{\circ} \mathrm{C}$, the percentage of iodide ions exchanged decreases from $61.80 \%$ to $59.80 \%$ while using Duolite ARA-9366B resins, the percentage of iodide ions exchanged decreases from $55.40 \%$ to $50.10 \%$. Similarly, in case of bromide ion-isotopic exchange reaction, the percentage of bromide ions exchanged decreases from $52.20 \%$ to $45.40 \%$ using Purolite NRW-5010 resin, while for Duolite ARA-9366B resin, it decreases from $48.30 \%$ to $40.60 \%$. The effect of temperature on percentage of ions exchanged is graphically represented in Figure 3.

The overall results indicate that under identical experimental conditions, as compared to Duolite ARA-9366B resins, Purolite NRW-5010 resins shows higher percentage of ions exchanged. Thus, Purolite NRW-5010 resins show superior performance over Duolite ARA-9366B resins under identical operational parameters.

\section{Statistical correlations}

The results of the present investigation show a strong negative correlation between the amount of ions exchanged and temperature of exchanging medium (Figures 4 and 5). In the case of iodide ion-isotopic exchange reactions, the values of $r$ calculated for Purolite NRW-5010 and Duolite 
Table 3 Concentration effect on ion-isotopic exchange reactions

\begin{tabular}{|c|c|c|c|c|c|c|c|c|c|c|c|c|c|}
\hline \multirow{3}{*}{$\begin{array}{l}\text { Concentration } \\
\text { of ionic } \\
\text { solution } \\
\text { (mol/L) }\end{array}$} & \multirow{3}{*}{$\begin{array}{l}\text { Amount } \\
\text { of ions in } \\
250 \mathrm{~mL} \\
\text { solution } \\
\text { (mmol) }\end{array}$} & \multicolumn{6}{|l|}{ Reaction (1) } & \multicolumn{6}{|l|}{ Reaction (2) } \\
\hline & & \multicolumn{3}{|c|}{ Duolite ARA-9366B } & \multicolumn{3}{|c|}{ Purolite NRW-5010 } & \multicolumn{3}{|c|}{ Duolite ARA-9366B } & \multicolumn{3}{|c|}{ Purolite NRW-5010 } \\
\hline & & $\begin{array}{l}\text { Specific } \\
\text { reaction } \\
\text { rate of rapid } \\
\text { process } \\
\left(\min ^{-1}\right)\end{array}$ & $\begin{array}{l}\text { Amount of } \\
\text { iodide ion } \\
\text { exchanged } \\
\text { (mmol) }\end{array}$ & $\begin{array}{l}\text { Initial } \\
\text { rate of } \\
\text { iodide ion } \\
\text { exchange } \\
\text { (mmol/min) }\end{array}$ & $\begin{array}{l}\text { Specific } \\
\text { reaction } \\
\text { rate of rapid } \\
\text { process } \\
\left(\min ^{-1}\right)\end{array}$ & $\begin{array}{l}\text { Amount of } \\
\text { iodide ion } \\
\text { exchanged } \\
\text { (mmol) }\end{array}$ & $\begin{array}{l}\text { Initial } \\
\text { rate of } \\
\text { iodide ion } \\
\text { exchanged } \\
\text { (mmol/min) }\end{array}$ & $\begin{array}{l}\text { Specific } \\
\text { reaction } \\
\text { rate of rapid } \\
\text { process } \\
\left(\min ^{-1}\right)\end{array}$ & $\begin{array}{l}\text { Amount } \\
\text { of bromide } \\
\text { ion exchanged } \\
(\mathrm{mmol})\end{array}$ & $\begin{array}{l}\text { Initial rate } \\
\text { of bromide } \\
\text { ion exchange } \\
\text { ( } \mathrm{mmol} / \mathrm{min})\end{array}$ & $\begin{array}{l}\text { Specific } \\
\text { reaction } \\
\text { rate of rapid } \\
\text { process } \\
\left(\min ^{-1}\right)\end{array}$ & $\begin{array}{l}\text { Amount of } \\
\text { bromide ion } \\
\text { exchanged } \\
\text { (mmol) }\end{array}$ & $\begin{array}{l}\text { Initial } \\
\text { rate of } \\
\text { bromide } \\
\text { ion exchange } \\
\text { (mmol/min) }\end{array}$ \\
\hline \multirow[t]{3}{*}{0.001} & 0.250 & 0.201 & 0.139 & 0.028 & 0.246 & 0.155 & 0.038 & 0.165 & 0.121 & 0.020 & 0.203 & 0.131 & 0.026 \\
\hline & & & $\begin{array}{l}A_{i}=15,560 \\
\mathrm{cpm}\end{array}$ & & & $\begin{array}{l}A_{i}=16,010 \\
\mathrm{cpm}\end{array}$ & & & $\begin{array}{l}A_{i}=16,532 \\
\mathrm{cpm}\end{array}$ & & & $\begin{array}{l}A_{i}=16,229 \\
\mathrm{cpm}\end{array}$ & \\
\hline & & & $\begin{array}{l}A_{f}=6,909 \\
\mathrm{cpm}\end{array}$ & & & $\begin{array}{l}A_{f}=6,084 \\
\mathrm{cpm}\end{array}$ & & & $\begin{array}{l}A_{f}=8,531 \\
\mathrm{cpm}\end{array}$ & & & $\begin{array}{l}A_{f}=7,725 \\
\text { cpm }\end{array}$ & \\
\hline \multirow[t]{3}{*}{0.002} & 0.500 & 0.218 & 0.293 & 0.064 & 0.253 & 0.322 & 0.081 & 0.173 & 0.253 & 0.044 & 0.215 & 0.269 & 0.058 \\
\hline & & & $\begin{array}{l}A_{i}=16,009 \\
\mathrm{cpm}\end{array}$ & & & $\begin{array}{l}A_{i}=16,564 \\
\mathrm{cpm}\end{array}$ & & & $\begin{array}{l}A_{i}=16,176 \\
\mathrm{cpm}\end{array}$ & & & $\begin{array}{l}A_{i}=15,632 \\
\mathrm{cpm}\end{array}$ & \\
\hline & & & $\begin{array}{l}A_{f}=6,628 \\
\mathrm{cpm}\end{array}$ & & & $\begin{array}{l}A_{f}=5,897 \\
\mathrm{cpm}\end{array}$ & & & $\begin{array}{l}A_{f}=7,991 \\
\mathrm{cpm}\end{array}$ & & & $\begin{array}{l}A_{f}=7,222 \\
\mathrm{cpm}\end{array}$ & \\
\hline \multirow[t]{3}{*}{0.003} & 0.750 & 0.227 & 0.451 & 0.102 & 0.274 & 0.499 & 0.137 & 0.180 & 0.388 & 0.070 & 0.228 & 0.409 & 0.093 \\
\hline & & & $\begin{array}{l}A_{i}=15,543 \\
\mathrm{cpm}\end{array}$ & & & $\begin{array}{l}A_{i}=15,889 \\
\mathrm{cpm}\end{array}$ & & & $\begin{array}{l}A_{i}=15,579 \\
\mathrm{cpm}\end{array}$ & & & $\begin{array}{l}A_{i}=15,999 \\
\mathrm{cpm}\end{array}$ & \\
\hline & & & $\begin{array}{l}A_{f}=6,196 \\
\mathrm{cpm}\end{array}$ & & & $\begin{array}{l}A_{f}=5,318 \\
\mathrm{cpm}\end{array}$ & & & $\begin{array}{l}A_{f}=7,519 \\
\mathrm{cpm}\end{array}$ & & & $\begin{array}{l}A_{f}=7,274 \\
\mathrm{cpm}\end{array}$ & \\
\hline \multirow[t]{3}{*}{0.004} & 1.000 & 0.235 & 0.629 & 0.148 & 0.290 & 0.689 & 0.200 & 0.186 & 0.528 & 0.098 & 0.245 & 0.557 & 0.136 \\
\hline & & & $\begin{array}{l}A_{i}=15,877 \\
\mathrm{cpm}\end{array}$ & & & $\begin{array}{l}A_{i}=15,895 \\
\mathrm{cpm}\end{array}$ & & & $\begin{array}{l}A_{i}=15,953 \\
\mathrm{cpm}\end{array}$ & & & $\begin{array}{l}A_{i}=16,005 \\
\mathrm{cpm}\end{array}$ & \\
\hline & & & $\begin{array}{l}A_{f}=5,890 \\
\mathrm{cpm}\end{array}$ & & & $\begin{array}{l}A_{f}=4,943 \\
\mathrm{cpm}\end{array}$ & & & $\begin{array}{l}A_{f}=7,530 \\
\mathrm{cpm}\end{array}$ & & & $\begin{array}{l}A_{f}=7,090 \\
\mathrm{cpm}\end{array}$ & \\
\hline
\end{tabular}

Amount of ion exchange resin $=1.000 \mathrm{~g}$; volume of labeled ionic solution $=250 \mathrm{~mL}$; temperature $=30.0^{\circ} \mathrm{C}$. 
Table 4 Temperature effect on ion-isotopic exchange reactions

\begin{tabular}{|c|c|c|c|c|c|c|c|c|c|c|c|c|}
\hline \multirow[t]{3}{*}{ Temperature $\left({ }^{\circ} \mathrm{C}\right)$} & \multicolumn{6}{|l|}{ Reaction (1) } & \multicolumn{6}{|l|}{ Reaction (2) } \\
\hline & \multicolumn{3}{|c|}{ Duolite ARA-9366B } & \multicolumn{3}{|c|}{ Purolite NRW-5010 } & \multicolumn{3}{|c|}{ Duolite ARA-9366B } & \multicolumn{3}{|c|}{ Purolite NRW-5010 } \\
\hline & $\begin{array}{l}\text { Specific } \\
\text { reaction rate } \\
\text { of rapid } \\
\text { process } \\
\left(\min ^{-1}\right)\end{array}$ & $\begin{array}{l}\text { Amount of } \\
\text { iodide ion } \\
\text { exchanged } \\
\text { (mmol) }\end{array}$ & $\begin{array}{l}\text { Initial rate } \\
\text { of iodide } \\
\text { ion exchange } \\
\text { (mmol/min) }\end{array}$ & $\begin{array}{l}\text { Specific } \\
\text { reaction rate } \\
\text { of rapid } \\
\text { process } \\
\left(\min ^{-1}\right)\end{array}$ & $\begin{array}{l}\text { Amount of } \\
\text { iodide ion } \\
\text { exchanged } \\
\text { (mmol) }\end{array}$ & $\begin{array}{l}\text { Initial rate } \\
\text { of iodide } \\
\text { ion exchange } \\
\text { (mmol/min) }\end{array}$ & $\begin{array}{l}\text { Specific } \\
\text { reaction rate } \\
\text { of rapid } \\
\text { process } \\
\left(\min ^{-1}\right)\end{array}$ & $\begin{array}{l}\text { Amount } \\
\text { of bromide } \\
\text { ion exchanged } \\
(\mathrm{mmol})\end{array}$ & $\begin{array}{l}\text { Initial rate } \\
\text { of bromide } \\
\text { ion exchange } \\
\text { (mmol/min) }\end{array}$ & $\begin{array}{l}\text { Specific } \\
\text { reaction rate } \\
\text { of rapid } \\
\text { process } \\
\left(\mathrm{min}^{-1}\right)\end{array}$ & $\begin{array}{l}\text { Amount } \\
\text { of bromide } \\
\text { ion exchanged } \\
\text { ( } \mathrm{mmol} \text { ) }\end{array}$ & $\begin{array}{l}\text { Initial rate } \\
\text { of bromide } \\
\text { ion exchange } \\
\text { ( } \mathrm{mmol} / \mathrm{min} \text { ) }\end{array}$ \\
\hline \multirow[t]{3}{*}{30.0} & 0.201 & 0.139 & 0.028 & 0.246 & 0.155 & 0.038 & 0.165 & 0.121 & 0.020 & 0.203 & 0.131 & 0.026 \\
\hline & & $\begin{array}{l}A_{i}=15,560 \\
\mathrm{cpm}\end{array}$ & & & $\begin{array}{l}A_{i}=16,010 \\
\mathrm{cpm}\end{array}$ & & & $\begin{array}{l}A_{i}=16,532 \\
\mathrm{cpm}\end{array}$ & & & $\begin{array}{l}A_{i}=16,229 \\
\text { cpm }\end{array}$ & \\
\hline & & $\begin{array}{l}A_{f}=6,909 \\
\mathrm{cpm}\end{array}$ & & & $\begin{array}{l}A_{f}=6,084 \\
\mathrm{cpm}\end{array}$ & & & $\begin{array}{l}A_{f}=8,531 \\
\mathrm{cpm}\end{array}$ & & & $\begin{array}{l}A_{f}=7,725 \\
\mathrm{cpm}\end{array}$ & \\
\hline \multirow[t]{3}{*}{35.0} & 0.188 & 0.133 & 0.025 & 0.235 & 0.153 & 0.036 & 0.148 & 0.113 & 0.017 & 0.194 & 0.125 & 0.024 \\
\hline & & $\begin{array}{l}A_{i}=15,779 \\
\mathrm{cpm}\end{array}$ & & & $\begin{array}{l}A_{i}=15,043 \\
\mathrm{cpm}\end{array}$ & & & $\begin{array}{l}A_{i}=15,976 \\
\mathrm{cpm}\end{array}$ & & & $\begin{array}{l}A_{i}=16,101 \\
\mathrm{cpm}\end{array}$ & \\
\hline & & $\begin{array}{l}A_{f}=7,385 \\
\mathrm{cpm}\end{array}$ & & & $\begin{array}{l}A_{f}=5,837 \\
\text { cpm }\end{array}$ & & & $\begin{array}{l}A_{f}=8,755 \\
\text { cpm }\end{array}$ & & & $\begin{array}{l}A_{f}=8,050 \\
\text { cpm }\end{array}$ & \\
\hline \multirow[t]{3}{*}{40.0} & 0.170 & 0.129 & 0.022 & 0.228 & 0.150 & 0.034 & 0.137 & 0.106 & 0.014 & 0.185 & 0.120 & 0.022 \\
\hline & & $\begin{array}{l}A_{i}=15,834 \\
\mathrm{cpm}\end{array}$ & & & $\begin{array}{l}A_{i}=15,756 \\
\mathrm{cpm}\end{array}$ & & & $\begin{array}{l}A_{i}=15,473 \\
\mathrm{cpm}\end{array}$ & & & $\begin{array}{l}A_{i}=15,998 \\
\mathrm{cpm}\end{array}$ & \\
\hline & & $\begin{array}{l}A_{f}=7,664 \\
\mathrm{cpm}\end{array}$ & & & $\begin{array}{l}A_{f}=6,302 \\
\text { cpm }\end{array}$ & & & $\begin{array}{l}A_{f}=8,912 \\
\text { cpm }\end{array}$ & & & $\begin{array}{l}A_{f}=8,319 \\
\text { cpm }\end{array}$ & \\
\hline \multirow[t]{3}{*}{45.0} & 0.156 & 0.125 & 0.020 & 0.219 & 0.150 & 0.033 & 0.125 & 0.102 & 0.013 & 0.178 & 0.114 & 0.020 \\
\hline & & $\begin{array}{l}A_{i}=15,601 \\
\mathrm{cpm}\end{array}$ & & & $\begin{array}{l}A_{i}=15,539 \\
\mathrm{cpm}\end{array}$ & & & $\begin{array}{l}A_{i}=16,001 \\
\mathrm{cpm}\end{array}$ & & & $\begin{array}{l}A_{i}=15,678 \\
\mathrm{cpm}\end{array}$ & \\
\hline & & $\begin{array}{l}A_{f}=7,800 \\
\mathrm{cpm}\end{array}$ & & & $\begin{array}{l}A_{f}=6,216 \\
\mathrm{cpm}\end{array}$ & & & $\begin{array}{l}A_{f}=9,473 \\
\mathrm{cpm}\end{array}$ & & & $\begin{array}{l}A_{f}=8,529 \\
\mathrm{cpm}\end{array}$ & \\
\hline
\end{tabular}

Amount of ion exchange resin $=1.000 \mathrm{~g}$. Concentration of labeled exchangeable ionic solution $=0.001 \mathrm{~mol} / \mathrm{L}$. Volume of labeled ionic solution $=250 \mathrm{~mL}$. Amount of exchangeable ions in $250 \mathrm{~mL}$ labeled solution $=0.250 \mathrm{mmol}$. 


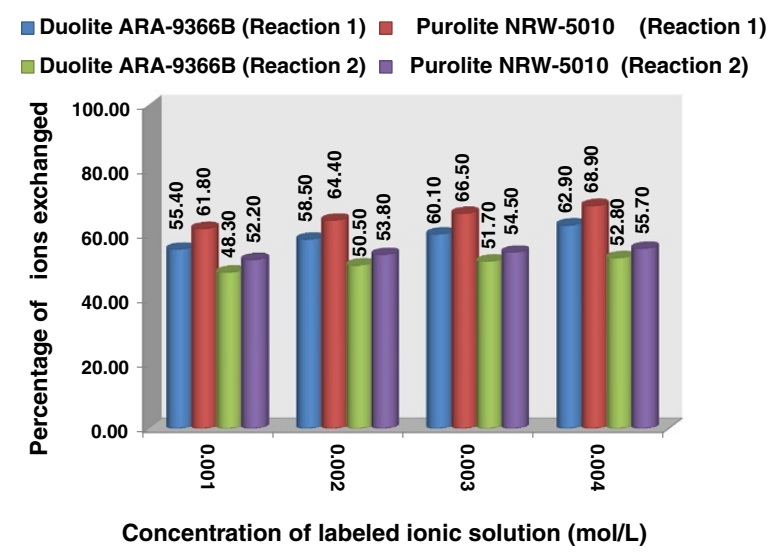

Figure 2 Variation in percentage ions exchanged with concentration of labeled ionic solution. Amount of ion exchange resin $=1.000 \mathrm{~g}$. Volume of labeled ionic solution $=250 \mathrm{~mL}$. Temperature $=30.0^{\circ} \mathrm{C}$

ARA-9366B resins were -0.9487 and -0.9944 , respectively. Similarly, in the case of bromide ion-isotopic exchange reactions, the $r$ values calculated were -0.9994 and -0.9899 , respectively, for both the resins.

\section{Conclusion}

Extensive work reported in the literature on synthesis of new ion exchange materials and their characterization itself is an indication that these resins are the wave of the present research and the material of new generation. Although there are a number of techniques reported in the literature on characterization of ion exchange resins,

$\square$ Purolite NRW-5010 (Reaction 1) $\square$ Duolite ARA-9366B (Reaction 1)
$\square$ Purolite NRW-5010 (Reaction 2) $\square$ Duolite ARA-9366B (Reaction 2)

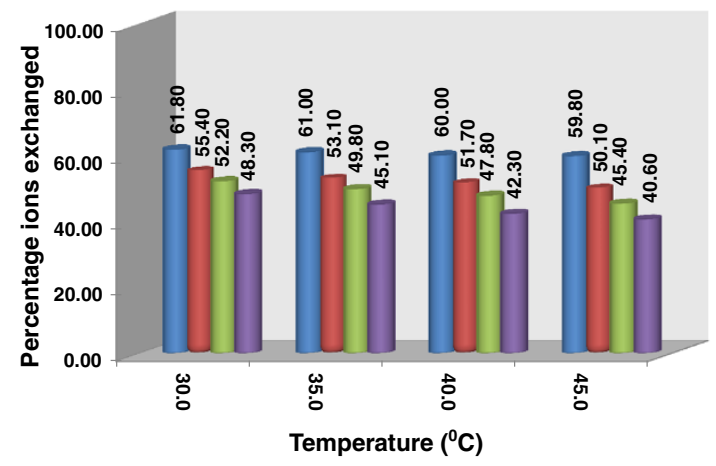

Figure 3 Variation in percentage ions exchanged with temperature of labeled ionic solution. Amount of ion exchange resin $=1.000 \mathrm{~g}$. Concentration of labeled exchangeable ionic solution $=0.001 \mathrm{~mol} / \mathrm{L}$. Volume of labeled ionic solution $=250 \mathrm{~mL}$. Amount of exchangeable ions in $250 \mathrm{~mL}$ labeled solution = $0.250 \mathrm{mmol}$.

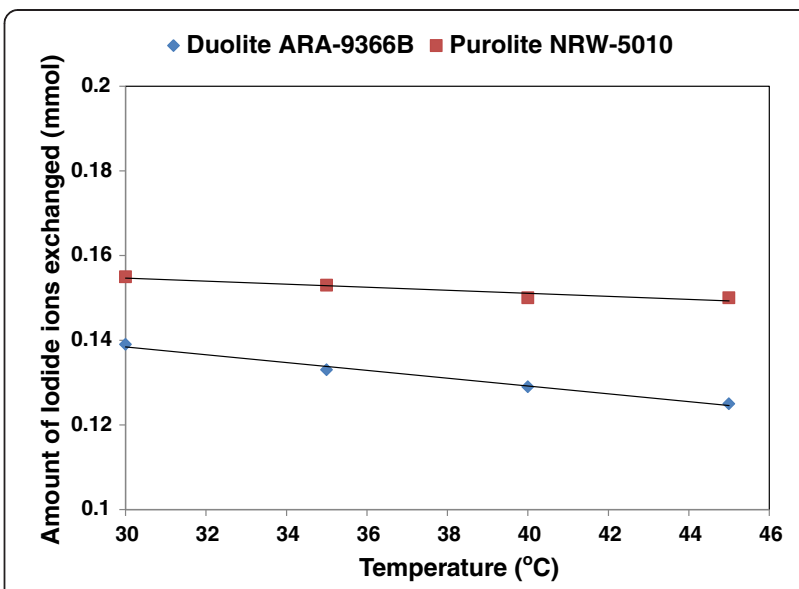

Figure 4 Correlation between temperature of exchanging medium and amount of iodide ion exchanged. Amount of ion exchange resin $=1.000 \mathrm{~g}$. Concentration of labeled exchangeable ionic solution $=0.001 \mathrm{~mol} / \mathrm{L}$. Volume of labeled ionic solution $=250 \mathrm{~mL}$. Amount of exchangeable ions in $250 \mathrm{~mL}$ labeled solution $=0.250 \mathrm{mmol}$. Correlation coefficient $(r)$ for Duolite ARA-9366B $=-0.9944$. Correlation coefficient $(r)$ for Purolite NRW-5010 $=-0.9487$.

the radioisotopic tracer technique has emerged as one of the effective non-destructive analytical techniques. The present research paper therefore is a successful demonstration on the application of radiotracer isotopes in the characterization of nuclear grade ion exchange resins Duolite ARA-9366B and Purolite NRW-5010. The results

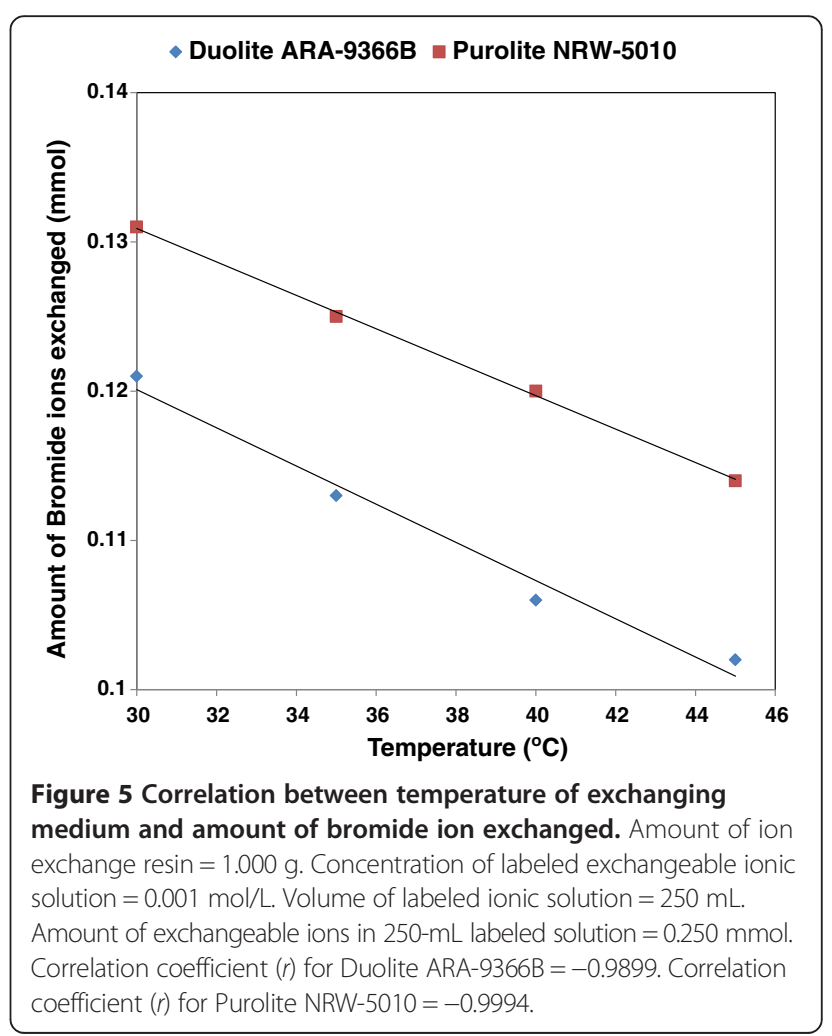


of the present investigation may help to optimize the operational process parameters for efficient performance of these resins in various technical applications. The same technique can also be extended further for characterization of different non-nuclear grade ion exchange resins. It is anticipated that the results of such work will be useful in deciding about the selection of the resins in various industrial applications.

\section{Competing interests}

The author declares that there is no competing interests.

Received: 29 September 2013 Accepted: 18 March 2014

Published online: 02 April 2014

\section{References}

Bray LA, Elovich RJ, Carson KJ (1990) Cesium recovery using Savannah River laboratory resorcinol-formaldehyde ion exchange resin. Pacific Northwest Lab, Richland, WA, Rep PNL-7273

Clark MW, Harrison JJ, Payne TE (2011) The pH-dependence and reversibility of uranium and thorium binding on a modified bauxite refinery residue using isotopic exchange techniques. J Colloid Interface Sci 356(2):699-705

Dagadu CPK, Akaho EHK, Danso KA, Stegowski Z, Furman L (2012) Radiotracer investigation in gold leaching tanks. Appl Radiat Isot 70(1):156-161

de Villiers JP, Parrish JR (1964) Rapid characterization of ion-exchange resins by NMR. J Polym Sci Part A: Gen Papers 2(3):1331-1340

Harland CE (1994) lon exchange, 2nd edn. RSC Publishing, UK, pp 49-89. doi:10.1039/9781847551184-00049, elSBN: 978-1-84755-118-4. ISBN 978-0-85186-484-6

International Atomic Energy Agency (IAEA) Vienna (2002) Application of ion exchange processes for the treatment of radioactive waste and management of spent ion exchangers. Technical reports series no. 408. International Atomic Energy Agency (IAEA), Vienna, Austria

International Atomic Energy Agency (IAEA) Vienna (2004) Radiotracer applications in industry - a guidebook. Technical reports series no.423. International Atomic Energy Agency (IAEA), Vienna, Austria

Koron N, Bratkic A, Ribeiro Guevara S, Vahcic M, Horvat M (2012) Mercury methylation and reduction potentials in marine water: an improved methodology using ${ }^{197} \mathrm{Hg}$ radiotracer. Appl Radiat Isot 70(1):46-50

Kulkarni Y, Samanta SK, Bakre SY, Raj K, Kumra MS (1996) Process for treatment of intermediate level radioactive waste based on radionuclide separation. Waste management'96 (Proc Int Symp Tucson, AZ, 1996). Arizona Board of Regents, Phoenix, AZ (CD-ROM)

Kumaresan R, Sabharwal KN, Srinivasan TG, Vasudeva Rao PR, Dhekane G (2006) Evaluation of new anion exchange resins for plutonium processing. Solvent Extr lon Exc 24(4):589-602

Liu H, Zhang S, Nie S, Zhao X, Sun X, Yang X, Pan W (2005) Preparation and characterization of a novel $\mathrm{pH}$-sensitive ion exchange resin. Chem Pharm Bull (Tokyo) 53(6):631-633

Lokhande RS, Singare PU (2007) Comparative study on ion-isotopic exchange reaction kinetics by application of tracer technique. Radiochim Acta 95 (03):173-176

Lokhande RS, Singare PU (2008) Comparative study on iodide and bromide ion-isotopic exchange reactions by application of radioactive tracer technique. J Porous Mater 15(03):253-258

Lokhande RS, Singare PU, Dole MH (2006) Comparative study on bromide and iodide ion-isotopic exchange reactions using strongly basic anion exchange resin duolite A-113. J Nucl Radiochem Sci 7(2):29-32

Lokhande RS, Singare PU, Patil W (2008a) Application of radioactive tracer technique to study the kinetics and mechanism of reversible ion-isotopic exchange reaction using strongly basic anion exchange resin indion -850 . Radiochemistry 50(6):638-641

Lokhande RS, Singare PU, Prabhavalkar TS (2008b) The application of the radioactive tracer technique to study the kinetics of bromide isotope exchange reaction with the participation of strongly basic anion exchange resin indion FF-IP. Russ J Phys Chem A 82(9):1589-1595

Masram DT, Kariya KP, Bhave NS (2010) A novel resin sef: synthesis, characterization and ion-exchange properties. Appl Sci Segment 1(1):APS/1513
Patel SA, Shah BS, Patel RM, Patel PM (2004) Synthesis, characterization and ion exchange properties of acrylic copolymers derived from 8-quinolinyl methacrylate. Iran Polym J 13(6):445-453

Samanta SK, Ramaswamy M, Misra BM (1992) Studies on cesium uptake by phenolic resins. Sep Sci Technol 27:255-267

Samanta SK, Ramaswamy M, Sen P, Varadarajan N, Singh RK (1993) Removal of radiocesium from alkaline $\mathrm{IL}$ waste. Natl symp on management of radioactive and toxic wastes (SMART-93). Kalpakkam, Bhabha Atomic Research Centre, Bombay, pp 56-58

Samanta SK, Theyyunni TK, Misra BM (1995) Column behavior of a resorcinolformaldehyde polycondensate resin for radiocesium removal from simulated solution. J Nucl Sci Technol 32:425-429

Singare PU, Lokhande RS (2012) Studies on ion-isotopic exchange reactions using nuclear grade ion exchange resins. lonics 18(4):351-357

Sood DD, Reddy AVR, Ramamoorthy N (2004) Applications of radioisotopes in agriculture and industry. In: Fundamentals of radiochemistry. Indian Association of Nuclear Chemists and Allied Scientists (IANCAS), Mumbai, India. pp 289-297

Tomoi M, Yamaguchi K, Ando R, Kantake Y, Aosaki Y, Kubota H (1997) Synthesis and thermal stability of novel anion exchange resins with spacer chains. J Appl Poly Sci 64(6):1161-1167

Zeng X, Murray GM (1996) Synthesis and characterization of site-selective ion-exchange resins templated for lead (II) ion. Sep Sci Technol 31(17):2403-2418

Zhu L, Liu Y, Chen J (2009) Synthesis of N-methylimidazolium functionalized strongly basic anion exchange resins for adsorption of $\mathrm{Cr}(\mathrm{VI})$. Ind Eng Chem Res 48(7):3261-3267

doi:10.1186/s40543-014-0030-5

Cite this article as: Singare: Radio analytical technique in

characterization of nuclear grade ion exchangers Duolite ARA-9366B and Purolite NRW-5010. Journal of Analytical Science and Technology 2014 5:30.

\section{Submit your manuscript to a SpringerOpen ${ }^{\odot}$ journal and benefit from:}

- Convenient online submission

Rigorous peer review

- Immediate publication on acceptance

- Open access: articles freely available online

- High visibility within the field

- Retaining the copyright to your article

Submit your next manuscript at $>$ springeropen.com 